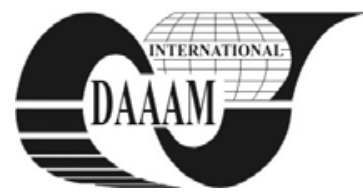

Annals of DAAAM for 2011 \& Proceedings of the 22nd International DAAAM Symposium, Volume 22, No. 1, ISSN 1726-9679 ISBN 978-3-901509-83-4, Editor B. Katalinic, Published by DAAAM International, Vienna, Austria, EU, 2011 Make Harmony between Technology and Nature, and Your Mind will Fly Free as a Bird Annals \& Proceedings of DAAAM International 2011

\title{
FUEL COMBUSTION WITH MONITORED MODERATE UNDERBURNING
}

\author{
ROSLYAKOV, P[avel] V[asilievich]; PLESHANOV, K[onstantin] A[leksandrovich] \& IONKIN, I[gor] \\ L[vovich]
}

\begin{abstract}
In today's world, great attention is paid to energy efficiency equipment, and its impact on the environment. Quite often, increasing environmental safety of the boiler leads to a deterioration in performance of its work and vice versa. This article presents new method of Fuel Combustion With Monitored Moderate Underburning, allowing not only significantly reduce emissions of nitrogen oxides, but also to improve technical and economic characteristics of power equipment.
\end{abstract}

Key words: boiler, environmental protection, NOx, underburning, CO measurement

\section{INTRODUCTION}

Presently, the technical arsenal of power-generating boilers used in Russia consists in its major part of units that were commissioned before the late 1980s. The characteristic feature of those technologies consisted of subjecting fuel and oxidizer to intense premixing for reducing the fractions of incomplete combustion and unburned carbon (Lipov Y.M., Tretyakov Y.M., 2003). As a result, fuel was fired under the conditions of high local air excess factors, high temperatures.

Efforts taken in the past years to reduce the amount of harmful substances emitted with flue gases into the atmosphere have radically altered the philosophy of fuel combustion. In order to reduce emission of nitrogen oxides $\left(\mathrm{NO}_{\mathrm{x}}\right)$, combustion of fuel is presently organized at low values of local air excess factors, lowered temperatures, and shorter time for which fuel dwells in the zone of active combustion. Various technologies for OFA combustion, biased burner firing and staged combustion have been developed and put in operation together with other intrafurnace measures (Roslyakov P.V., 2007), due to which the emissions of $\mathrm{NO}_{\mathrm{x}}$ have been reduced essentially to the levels prescribed by the relevant standards.

Experience gained from putting intrafurnace (technological) measures in use on operating boilers has shown that with old designs of furnace devices it was not possible to setup the optimal combination of conditions for suppressing generation of nitrogen oxides and achieving complete burnout of fuel. As a result, attempts to put technological measures in operation on such boilers usually entailed a drop of efficiency, less reliable operation, and less efficient reduction of $\mathrm{NO}_{\mathrm{x}}$ emissions as compared with those from new boilers.

\section{FUEL COMBUSTION WITH MONITORED MODERATE UNDERBURNING}

The new method of fuel combustion with monitored moderate underburning developed at the Moscow Power Engineering Institute (Roslyakov P.V. et all, 2009). The idea of this method is to reduce the content of oxygen in the zone of active combustion by decreasing the amount of air supplied into the boiler furnace in a controlled manner until moderate incomplete combustion occurs. In this case, generation of both thermal and fuel $\mathrm{NO}_{\mathrm{x}}$ in the combustion zone is suppressed by $20-40 \%$ with a parallel controlled increase in the content of carbon monoxide (CO) in flue gases to $50-150 \mathrm{mg} / \mathrm{m}^{3 *}$ (Fig. 1).

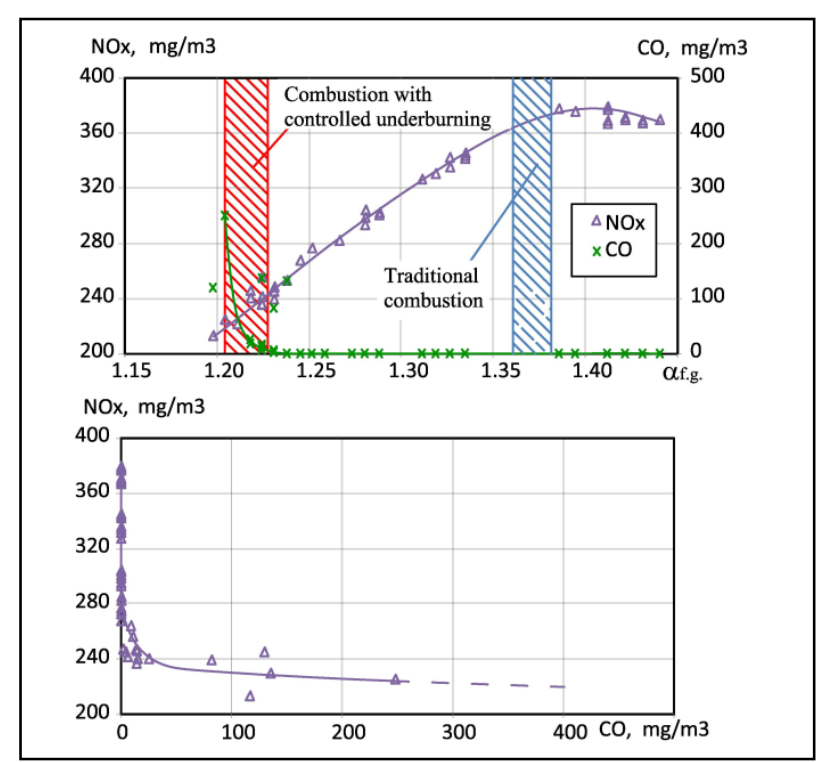

Fig. 1. Concentration of $\mathrm{NO}_{\mathrm{x}}$ and $\mathrm{CO}$ in flue gases form the BKZ-75-3,9GM boiler during firing of natural gas, $D=75 \mathrm{t} / \mathrm{h}$

The proposed combustion method can be used for any kind of organic fuel. Not only does this method allow $\mathrm{NO}_{\mathrm{x}}$ emissions to be reduced, but it also allows a somewhat higher boiler gross and net efficiency to be obtained due to a lower quantity of heat lost with exhaust gases and lower consumption of energy for the plant auxiliaries.

One argument voiced against the use of operating conditions with moderate underburning of fuel is that they entail an increased emission of benz(a)pyrene $\mathrm{C}_{20} \mathrm{H}_{12}$ (Fig. 2). Benz(a)pyrene as detrimental combustion product is more toxic than $\mathrm{NO}_{\mathrm{x}}$. Unbiased assessment of the environmental indicators characterizing different fuel combustion modes can be given only taking into account the toxicity of different detrimental combustion products $\left(\mathrm{NO}_{\mathrm{x}}, \mathrm{CO}\right.$, and $\left.\mathrm{C}_{20} \mathrm{H}_{12}\right)$ and the mass quantities in which they are emitted.

Experimental investigations were carried out on more than 10 different boilers with steam outputs ranging from 75 to 500 $\mathrm{t} / \mathrm{h}$. The environmental safety of different modes of natural gas combustion was determined in terms of the resulting nuisance value $\Pi_{\Sigma}$ of combustion products composed of the partial nuisance values of $\mathrm{NO}_{\mathrm{x}}, \mathrm{CO}$, and $\mathrm{C}_{20} \mathrm{H}_{12}$ in flue gases, that takes into account different toxicity and mass discharge of these detrimental combustion products

$$
\Pi_{\Sigma}=\Pi_{N O_{x}}+\Pi_{C O}+\Pi_{B(a) P}
$$

* The values of all quantities given in the text and in the figures are brought to standard conditions: temperature, $0{ }^{\circ} \mathrm{C}$; pressure, $101.3 \mathrm{kPa}$; and air excess factor in gases, $\alpha=1,4$. 


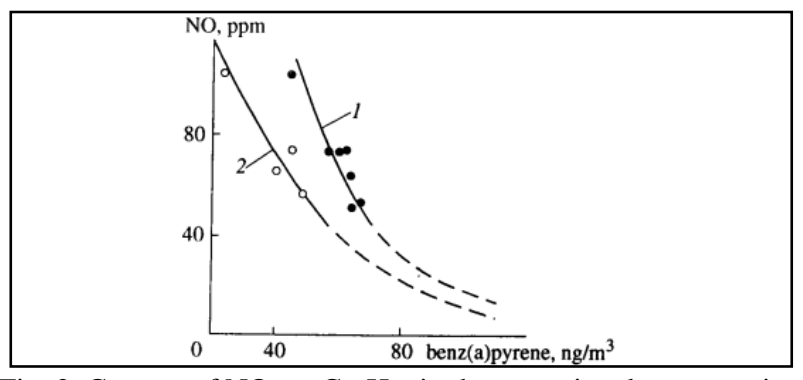

Fig. 2. Content of $\mathrm{NO}$ vs. $\mathrm{C}_{20} \mathrm{H}_{12}$ in the operational cross section (1) and the exhaust (2) in a TPE-430 boiler (fuel - natural gas)

Calculations of $\Pi_{\mathrm{i}}$ and $\Pi_{\Sigma}$ carried out on the basis of test results have shown that $\mathrm{NO}_{\mathrm{x}}$ are the largest contributor (90$98 \%$ ) in the total nuisance value of the detrimental combustion products emitted into the atmosphere. Therefore, to make the combustion of natural gas and fuel oil environmentally safer, the emission of $\mathrm{NO}_{\mathrm{x}}$ has to be reduced first of all. The contribution the emissions of $\mathrm{CO}$ and $\mathrm{C}_{20} \mathrm{H}_{12}$ introduce in the total nuisance value of flue gases increases only to $7-8 \%$. Total nuisance value in modes with moderate underburning is a factor of 1.5-2.0 smaller than during usual combustion.

Boiler efficiency (firing rate) is determined by the sum of heat losses with exhaust gases $q_{2}$, incomplete combustion $q_{3}$ (during the firing of gas and fuel oil). Implementation of technological measures in operating boilers usually causes their efficiency to degrade due to a higher value of $q_{2}$ resulting from higher temperature of flue gases. The advantage of the proposed method is that the boiler efficiency increases first in a certain range of decrease in the air excess factor due to a smaller loss of heat with flue gases (gross efficiency) and smaller consumption of energy for driving forced draft fans (net efficiency). As the air excess factor is decreased further, $q_{3}$ will increase faster than $q_{2}$ will decrease, due to which the function $\eta=f(\alpha)$ will have a maximum. The experiments that were carried out have shown that the minimal overall loss of heat with flue gases and incomplete combustion $\left(q_{2}+q_{3}\right)$ (Fig. 3) and, the minimal consumption of fuel for the boiler are observed in the region of reduced air excess factors during firing of fuel with moderate incomplete combustion with the content of CO in flue gases not more than $150 \mathrm{mg} / \mathrm{m}^{3}$.

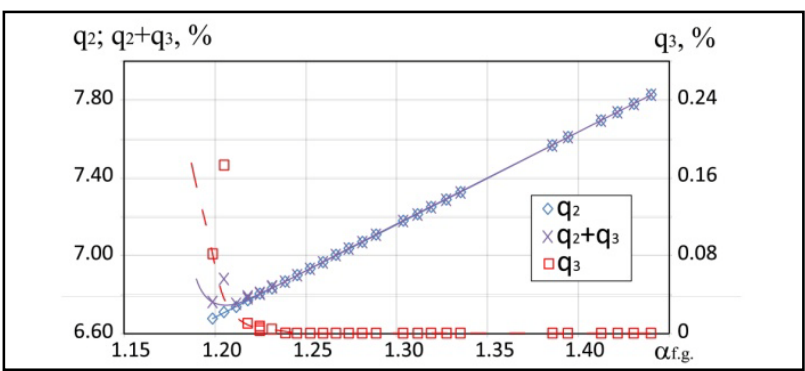

Fig. 3. Losses $q_{2}$ and $q_{3}$ vs. air excess factor in flue gases from the boiler (fuel - natural gas), TGM-84B boiler, $D=370-380 \mathrm{t} / \mathrm{h}$

Experimental dependences of efficiency vs. air excess factor in flue gases and content of $\mathrm{CO}$ in combustion products (Fig. 4, 5) were constructed for determining the optimal value of incomplete combustion (Fig. 5), which is monitored during operation from the content of $\mathrm{CO}$ in flue gases. The maximal values of efficiency are achieved in boilers of different types and with different steam outputs $(D=75-500 \mathrm{t} / \mathrm{h})$ during firing of natural gas with the content of $\mathrm{CO}$ in combustion products ranging from 50 to $100 \mathrm{mg} / \mathrm{m}^{3}$. When a shift is made for firing natural gas with moderate incomplete combustion, the gross efficiency of boilers increases by $0.5-1.0 \%$, an additional increase in the net efficiency by $0.05-0.1 \%$ is also obtained.

It should be pointed out that operation under conditions with low air excess factors and monitored moderate underbuming imposes more stringent requirements on the state

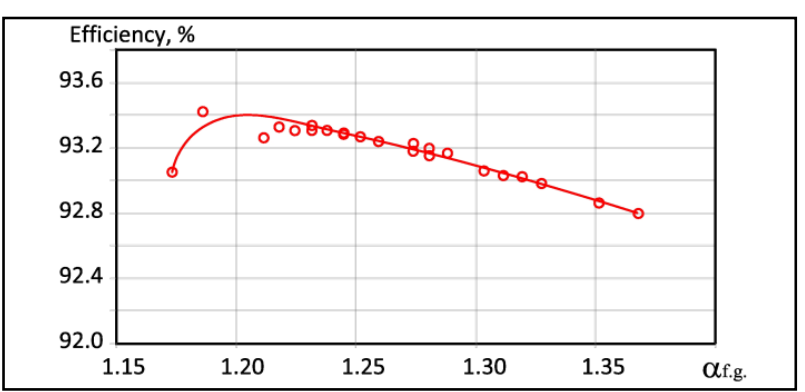

Fig. 4. Variation of efficiency with air excess factor in flue gases of boiler TsKTI-75-3,9, D=82 t/h (fuel - natural gas)

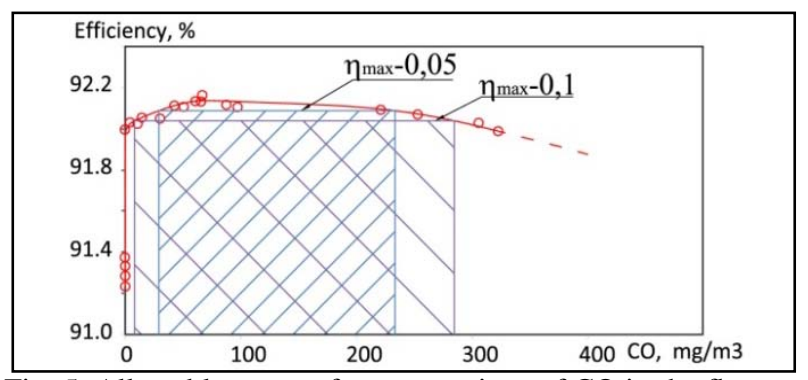

Fig. 5. Allowable range of concentrations of $\mathrm{CO}$ in the flue gas of boiler BKZ-75-3,9GM, $D=75 \mathrm{t} / \mathrm{h}$ (fuel - natural gas)

of a boiler unit, on the operation of instrumentation and control systems, on the skills of operating personnel, and on the observance of technological regulations.

Those shifting boilers that are now in operation for the fuel combustion with monitored moderate underburning should pay special attention to instrument-assisted monitoring of the fuel combustion process. The need for doing so stems from the fact that such operating mode is conducted in rather a narrow range of air excess factors.

\section{CONCLUSION}

Developed technology of fuel combustion with monitored moderate underburning is recommended for gas and oil boilers subcritical pressure steam outputs less $500 \mathrm{t} / \mathrm{h}$. It is possible to reduce the emissions of $\mathrm{NO}_{\mathrm{x}}$ by $20-40 \%$ and, in parallel with this, to increase the boiler efficiency by $0,5-1 \%$.

The experimental data have shown that the maximal content of $\mathrm{CO}$ reached in flue gases emission should not exceed $50-100 \mathrm{mg} / \mathrm{m}^{3}$. The most efficient and environmentally safe operation of the boiler will in this case be obtained.

Next stages of developing technology consist of two directions. First are the experiments on the automated control of the boilers. Continuous measurement of $\mathrm{O}_{2}, \mathrm{NO}$ and $\mathrm{CO}$ in different cross sections of gas flue allows to optimize air/fuel ratio and work of the boiler. Second is the combination of fuel combustion with monitored moderate underburning with other technological measures of the emissions of $\mathrm{NO}_{\mathrm{x}}$ reduce.

It need to takes further research to make introduction of fuel combustion with monitored moderate underburning at coal boilers. They should find out the effect of this method of combustion on the reliability of the boiler (slagging furnace waterwalls, deposit of carbon at the heating surface, etc.).

\section{REFERENCES}

Lipov Y.M. \& Tretyakov Y.M. (2003). Boilers and steam generators, ICS "Regular and Chaotic Dynamics", ISBN 593972-227-X, Moscow-Izhevsk

Roslyakov P.V. (2007), Methods for Protecting the Environment, MEI, ISBN 978-5-383-00056-4, Moscow

Roslyakov P.V., Ionkin I.L., \& Pleshanov K.A. (2009), Efficient Combustion of Fuels with Controlled Chemical Underburning. Teploenergetika, No. 1, 20-23 [Therm. Eng., Vol. 56, No. 1 pp. 22-25, ISSN 0040-6015] 